\title{
Effect of the protein elicitor AMEP412 from Bacillus subtilis artificially fed to adults of the whitefly, Bemisia tabaci (Genn.) (Hemiptera: Aleyrodidae)
}

\author{
Quan Liu* (D), Binbin Zhang, Yongrui Shen and Kuide Yin
}

\begin{abstract}
In a previous study, we identified a protein elicitor AMEP412 from Bacillus subtilis, which could trigger plant defense response and induce systemic acquired resistance. In the present study, the toxicity of AMEP412 against the whitefly Bemisia tabaci (Genn.) (Hemiptera: Aleyrodidae) was reported. The purified protein samples at different concentrations (1, 5, 10, 20, 40, and $80 \mu \mathrm{g} / \mathrm{ml}$ ) caused $17-96 \%$ mortality 2 days post-artificial adult feeding, where the median lethal concentration ( $L C_{50}$ ) was calculated by $15.57 \mathrm{\mu g} / \mathrm{ml}$. The stability test showed that AMEP412 had a good stability against thermo and natural degradation. The fluorescence localization assay revealed that AMEP412 could be taken into the whitefly adult body and localized in the gut. Based on the feature of this protein, AMEP412 was probably digested by gut proteases and led to the release of hydrophobic fragments in the insect gut. It was deduced that these hydrophobic peptides could insert themselves into the cell membrane and form lytic pores, leading to content leakage and cell lysis, followed by insect death. This study sheds a light on the toxic effect of AMEP412, which not only enriched the function of the protein elicitor but also provided a new choice for the biocontrol of whiteflies.
\end{abstract}

Keywords: Biocontrol, Bacillus subtilis, Bemisia tabaci, Insecticidal protein, Stability

\section{Background}

The whitefly Bemisia tabaci (Genn.) (Hemiptera: Aleyrodidae) is an important insect pest to several crops, including vegetables, cotton, and ornamentals (Byrne and Bellows 1991). It damages crops by feeding on phloem and transmitting plant viruses, leading to tremendous losses in agricultural production and national economies (Reitz 2007; Navas-Castillo et al. 2011). The main strategy of controlling the whitefly was mainly based on chemical insecticides. However, whitefly had developed resistance to those excessively and frequently applied insecticides (Wang et al. 2009; Luo et al. 2010; Houndété et al. 2010; Vassiliou et al. 2011; Kontsedalov et al. 2012). Considering this, exploring insecticides with novel mode of action should be a new focus.

Compared to chemical insecticides, proteins with insecticidal activity acted in different modes, which lead to

\footnotetext{
* Correspondence: 18765351@qq.com

College of Life Science and Technology, Heilongjiang Bayi Agricultural University, Daqing 163319, China
}

\section{Springer Open}

(c) The Author(s). 2020 Open Access This article is distributed under the terms of the Creative Commons Attribution 4.0 International License (http://creativecommons.org/licenses/by/4.0/), which permits unrestricted use, distribution, and reproduction in any medium, provided you give appropriate credit to the original author(s) and the source, provide a link to the Creative Commons license, and indicate if changes were made.

insect resistance with a relatively low probability. There were many reports about insecticidal proteins for pest control. The most famous example was Cry toxin of Bacillus thuringiensis $(B t)$, which was developed to Bt-transgenic cotton and effectively controlled the lepidopteran pest larvae. The widespread planting of $B t$-transgenic cotton significantly reduced the usage of chemical pesticides. However, none of the Cry toxins was reported effective on whiteflies. In recent years, several researchers focused on screening of insecticidal proteins from plants rarely infested by whiteflies. Das et al. (2009) reported a mannose binding lectin from leaves of Allium sativum that could effectively inhibit whiteflies. Jin et al. (2012) expressed the Pinellia ternata agglutinin in chloroplasts and conferred resistance against whiteflies. Shukla et al. (2016) identified an insecticidal protein (Tma12) from an edible fern and expressed it in transgenic cotton, which showed a high level of resistance to whiteflies. Although these insecticidal proteins showed a good potential for whitefly control, for the low extraction rate or the limit of 
transgenic plant, there were no matured commercial products in the market.

In a previous study, a protein elicitor (AMEP412) was isolated from Bacillus subtilis, which could interact with plant and induce serials of defense reactions (Shen et al. 2019). The study aimed to determine the toxic effect of AMEP412 and provide a new choice for the biocontrol of whiteflies. The localization of this protein in the insect adults was detected by fluorescent labeling. Moreover, the stability of this protein against thermal and natural degradation treatment was also determined.

\section{Materials and methods}

\section{Bacterial strain and growth condition}

Bacillus subtilis strain BU412, deposited in China Center for Type Culture Collection (CCTCC M2016142), was used for the production of AMEP412. Yeast malt extract (YME) medium (Schaad et al. 2001) was used for growing the strain.

\section{Preparation of AMEP412 protein}

The protein AMEP412 was prepared by serials of purification steps from the supernatant of B. subtilis BU412 culture, following Shen et al. (2019). The culture was centrifuged to obtain the supernatant. The supernatant was filtered through 0.22- $\mu \mathrm{m}$ membrane to remove residues and then applied to AKTA Purifier system (Amersham Biosciences). The purification procedures included anion exchange chromatography and size exclusion chromatography, using Source 15Q 4.6/ 100 PE column and Superdex 75 10/300 GL column. The fraction of the target protein was collected and adjusted to 1 $\mathrm{mg} / \mathrm{ml}$ for further determination.

\section{Insect bioassay}

The artificial feeding of whiteflies followed the method described by Upadhyay et al. (2011). Adult whiteflies (1-2 days old) were aspirated from plant leaves into $50-\mathrm{ml}$ specimen tubes. The aqueous artificial diet consisted of 5\% yeast extract, and 30\% sucrose (Blackburn et al. 2005) was mixed with different concentrations of AMEP412 (1, 5, $10,20,40$, and $80 \mu \mathrm{g} / \mathrm{ml})$. The artificial diet without AMEP412 was set as control. Diet $(100 \mu \mathrm{l})$ was added between two stretched layers of UV-sterilized parafilm on the tube cap, and then, the tube cap was reversed to cover the tube, keeping the diet at inner side. At least 50 whitefly adults were taken in each tube and the experiment was performed three times. The bioassays were carried out for 2 days, and mortality was recorded by counting the dead whitefly adults at the bottom of the tube.

\section{Stability assay}

In our previous study, AMEP412 showed a good thermo stability as a protein elicitor. To test its thermo stability as insecticidal protein, AMEP412 was subjected to $95^{\circ} \mathrm{C}$ for 15 and $30 \mathrm{~min}$, respectively. Furthermore, the natural degradation of AMEP412 was also determined. The protein was placed in Eppendorf tube at room temperature for 24 and $48 \mathrm{~h}$, respectively. Then, the insecticidal activity of the protein $(60 \mu \mathrm{g} / \mathrm{ml})$ was determined after being exposed to different conditions as described above, with

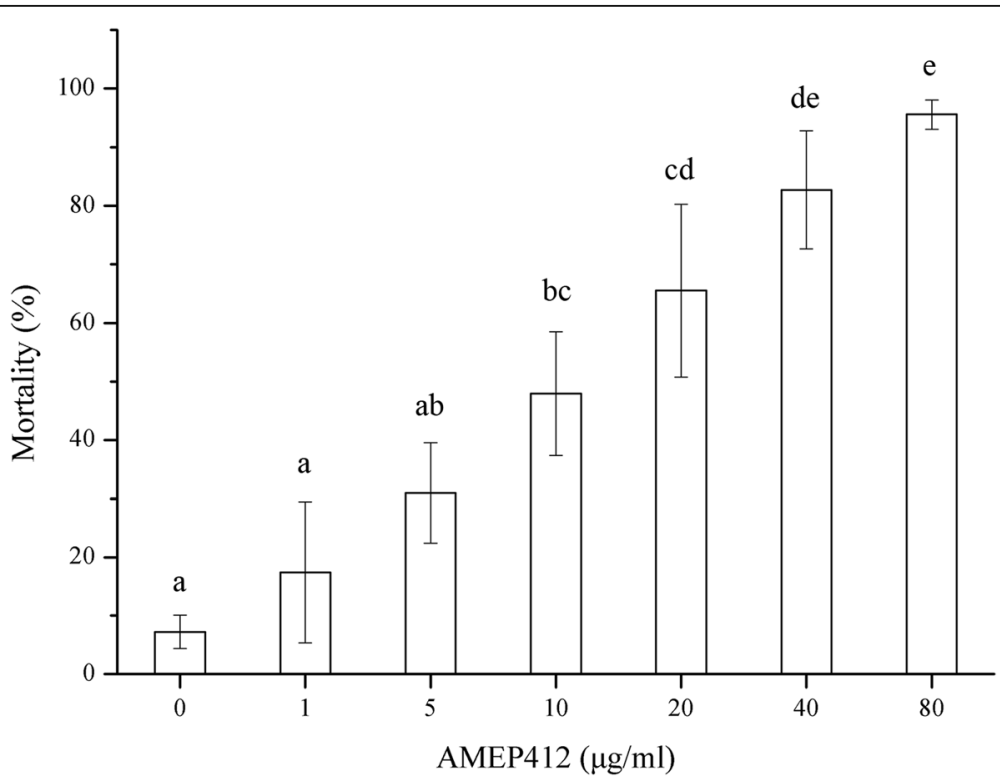

Fig. 1 Mortality of Bemisia tabaci adults fed on different concentrations of AMEP412. Means compared using Tukey's HSD test at $a=5 \%$; means superscripted with the same letter within a column are not significantly different 
Table 1 The calculated $L C_{50}$ of AMEP412 against B. tabaci

\begin{tabular}{lccccc}
\hline $\begin{array}{l}\mathrm{LC}_{50} \\
(\mu \mathrm{g} / \mathrm{ml})\end{array}$ & $\begin{array}{l}\text { Lower 95\% FL } \\
(\mu \mathrm{g} / \mathrm{ml})\end{array}$ & $\begin{array}{l}\text { Upper 95\% FL } \\
(\mu \mathrm{g} / \mathrm{ml})\end{array}$ & Slope $\pm \mathrm{SE}$ & $x^{2}(\mathrm{df})$ & $P$ value \\
\hline 15.57 & 10.86 & 21.00 & $2.10 \pm 0.28$ & $0.83(3)$ & 0.84
\end{tabular}

Slope and SE (standard error) refer to probit analysis

$95 \%$ fiducial limits $(F L)$ of $L C_{50}$ are given in parenthesis, respectively

Chi-square value $\left(x^{2}\right)$ and degrees of freedom (df) as calculated by SPSS

the untreated protein as control. Each treatment was repeated three times.

\section{In vivo localization}

As AMEP412 was purified from natural products, green fluorescent protein (GFP) tag was not suitable for labeling the protein. Instead, fluorescein isothiocyanate (FITC) was an ideal tag to label AMEP412. FITC-labeled AMEP412 was prepared, following the previous method (Shen et al. 2019). AMEP412 was incubated by FITC in carbonate buffer $(0.05 \mathrm{M}, \mathrm{pH} 9.0)$ for $12 \mathrm{~h}$ at $4{ }^{\circ} \mathrm{C}$. The FITC and protein mixture was loaded onto a Superdex $7510 / 300$ GL column for separation according to the different molecular sizes. Subsequently, $60 \mu \mathrm{g} / \mathrm{ml} \mathrm{FITC-}$ protein was used as insect diet for feeding bioassays as described above. Dead insects were collected, washed by sterile water, and then monitored by fluorescent microscope (Olympus BX60) with an excitation wavelength of $495 \mathrm{~nm}$ for the localization of the tested protein.

\section{Statistical analysis}

The mortality data for whitefly adults in above assays were analyzed by one-way ANOVA and the means were compared by Tukey's HSD test at $\alpha=5 \%$. The median lethal concentration $\left(\mathrm{LC}_{50}\right)$ value was calculated by the probit analysis on the SPSS program (version 18).

\section{Results and discussion \\ Insect bioassay}

The mortality of whitefly adults ranged from 17 to $96 \%$, showing a positive relationship with the concentrations of AMEP412 (Fig. 1). The $\mathrm{LC}_{50}$ value was calculated as $15.57 \mu \mathrm{g} / \mathrm{ml}$ (fiducial limits $=10.86-21.00$; slope $=2.10$; 95\% confidence interval (CI) for slope 1.55-2.66; $\chi 2$ for heterogeneity 0.83 calculated; $\chi 2$ significance value 0.84 ) (Table 1). AMEP412 caused $>90 \%$ mortality at $63.27 \mu \mathrm{g} /$ ml. In a previous study (Shen et al. 2019), AMEP412 was first reported as a protein elicitor with the function of eliciting plant's defense response and promoting plant's disease resistance. In this work, the toxic function of AMEP412 against whitefly was demonstrated. This meant that AMEP412 could affect both plant and insect with benefit to plant health. This kind of dual-function was rarely reported in other protein elicitors or insecticidal proteins, which could be a great advantage for the application of AMEP412.

\section{Stability test}

Compared to untreated AMEP412 samples (Fig. 2), treatments at $95^{\circ} \mathrm{C}$ for 15 and $30 \mathrm{~min}$ decreased the mortality rate of whiteflies by 0.57 and $0.49 \%$, respectively. This result showed that thermo treatment did not significantly affect the toxicity of AMEP412,

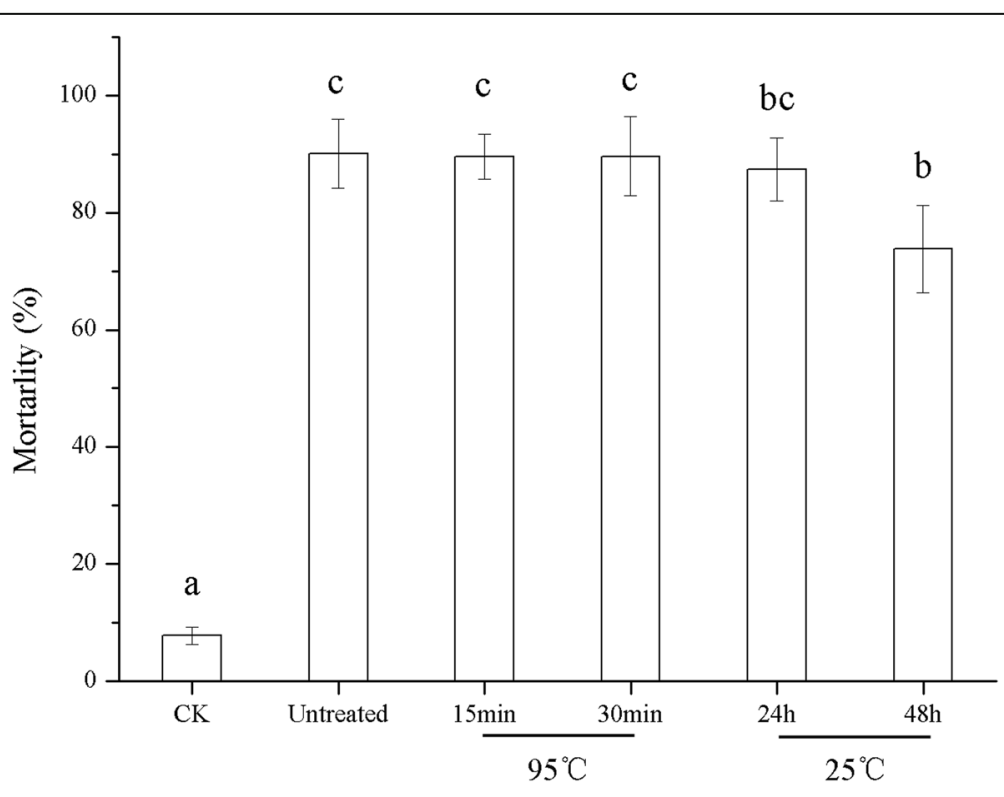

Treatment

Fig. 2 Mortality of Bemisia tabaci adults fed on AMEP412 subjected to thermal and natural degradation. Means compared using Tukey's HSD test at $a=5 \%$; means superscripted with same letter within a column are not significantly different 


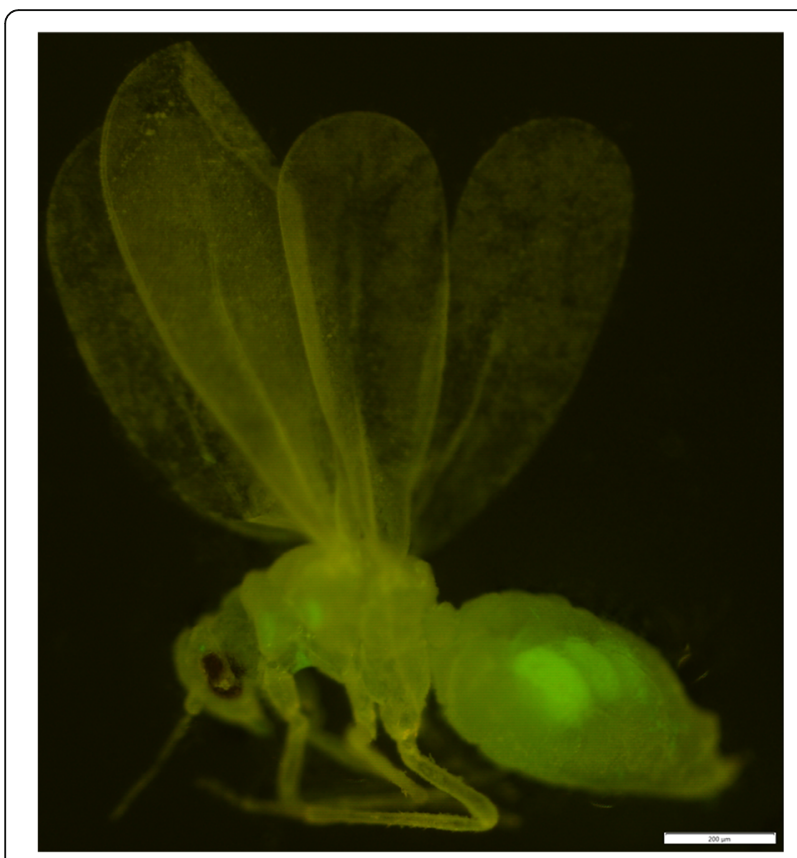

Fig. 3 The fluorescent localization of AME412 in Bemisia tabaci body

suggesting a good thermal stability of the protein. To check the natural degradation, AMEP412 was placed at room temperature for 24 and $48 \mathrm{~h}$. Compared to untreated AMEP412 samples, treatment at $25^{\circ} \mathrm{C}$ for 24 and $48 \mathrm{~h}$ decreased the mortality of whiteflies by 2.73 and $16.38 \%$, respectively. This result revealed that significant degradation of AMEP412 occurred in $48 \mathrm{~h}$. However, the sample still retained a majority of activity, which was regarded as a good stability against natural degradation. The results indicated that AMEP412 had good thermo stability and stayed stable with activity for about 2 days, which would be a great advantage for application.

AMEP412 showed a good stability against thermo and natural degradation, which was probably attributed to its stable spatial structure. As mentioned in a former study (Shen et al. 2019), AMEP412 formed polymers in aqueous environment, which enhanced its spatial structure against external interferences like thermo and natural degradation. Moreover, the polymerization state could also hide some enzyme digestion sites, leading to a certain resistance to enzymes. This feature will definitely broaden the application areas and improve the insecticidal effects.

\section{AMEP412 localized in whitefly guts}

As shown in Fig. 3, the fluorescence was mainly localized in the guts of the insect body. This result suggested that AMEP412 had been taken into the insect body and mainly localized in the guts, which indicated that AMEP412 exerted toxic activity in whitefly guts. Some insecticidal proteins acted as serine proteases (trypsin) inhibitors to interrupt the digestion function of insect gut, which finally lead to insect death (Macedo et al. 2010, 2011;Saadati and Bandani 2011). However, according to obtained results (data not shown), AMEP412 could not inhibit the activity of trypsin, suggesting that certain other mechanism was employed.

Beside serine proteases inhibitor, another kind of insecticidal protein functioned in insect gut was Cry toxin. Cry proteins, the crystal inclusion protoxins of B. thuringiensis, could be cleaved by gut proteases to yield Cry toxins. With hydrophobic character, Cry toxins could insert themselves into cell membrane and form lytic pores, which lead to ion leakage, cell lysis, and insect death (Aronson and Shai 2001; Bravo et al. 2005). The amino acid sequence analysis of AMEP412 revealed several trypsin cleavage sites (K), which were pointed out by an arrow in Fig. 4. The multiple cleavage sites indicated that AMEP412 was sensitive to trypsin cleavage. Another noticeable feature of AMEP412 was the highest content of hydrophobic amino acids (38 of 76 and $50 \%$, underlined in Fig. 4), indicating the highest probability of forming hydrophobic peptides after digestion. When soluble AMEP412 polymers were taken into insect guts, gut proteases like trypsin would digest the polymers from the surface, resulting in the release of hydrophobic fragments. It was deduced that these hydrophobic peptides had a possibility to insert themselves into the membrane of gut cell forced by hydrophobic interaction and form lytic pores, which further caused the release of cell contents even to insect death.

\section{Conclusion}

Insecticidal activity of AMEP412 against whitefly showed a good stability against thermo and natural degradation. The fluorescent localization revealed insect guts as its function position. The possible mechanism was discussed based on partial assay result and the feature of AMEP412. In future research, the exact mechanism will be clarified by studying the interaction between AMEP412 and whitefly gut cells. Moreover, the toxicity as insecticidal activity of AMEP412 against other insects will be investigated to fully understand its anti-insect spectrum.

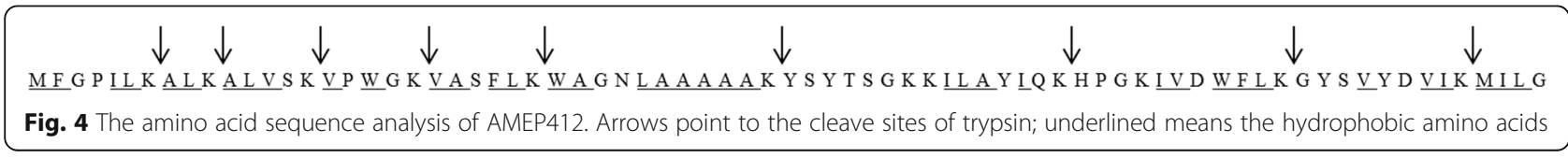




\section{Abbreviations}

Cl: Confidence interval; df: Degrees of freedom; FITC: Fluorescein isothiocyanate; GFP: Green fluorescent protein; LC50: Lethal concentration to kill 50\% population; SE: Standard error; YME: Yeast malt extract; X2: Chi-square

\section{Acknowledgements}

We thank the reviewers whose comments and suggestions helped us to improve this manuscript.

\section{Authors' contributions}

QL was the primary contributor to this study with helpful advice from BZ and YS. KY helped in the data analysis and revised the manuscript. All authors read and approved the final manuscript.

\section{Funding}

This work was financially supported by Natural Science Foundation of Heilongjiang Province of China (QC2017020), Postdoctoral Science Foundation of Heilongjiang Bayi Agricultural University, Innovation Training Program for College Students in Heilongjiang Province (201910223048) and Heilongjiang Bayi Agricultural University Support Program for San Heng San Zong (ZRCQC201904).

\section{Availability of data and materials}

Not applicable.

\section{Ethics approval and consent to participate}

Not applicable.

\section{Consent for publication}

Not applicable.

\section{Competing interests}

The authors declare that they have no competing interests.

Received: 30 October 2019 Accepted: 27 December 2019

Published online: 16 January 2020

\section{References}

Aronson Al, Shai Y (2001) Why Bacillus thuringiensis insecticidal toxins are so effective: unique features of their mode of action. FEMS Microbiol Lett 195:1-8

Blackburn MB, Domek JM, Gelman DB, Hu JS (2005) The broadly insecticidal Photorhabdus luminescens toxin complex a (Tca): activity against the Colorado potato beetle, Leptinotarsa decemlineata, and sweet potato whitefly, Bemisia tabaci. J Insect Sci 5:32

Bravo A, Gill SS, Soberón M (2005) Bacillus thuringiensis mechanisms and use in: comprehensive molecular insect science. Elsevier BV, Amsterdam, pp 175-206

Byrne DN, Bellows TS Jr (1991) Whitefly biology. Annu Rev Entomol 36:431-457

Das S, Banerjee S, Majumder P, Mondal HA, Saha P, Chakraborti D (2009) A mannose binding lectin from leaves of Allium sativum effective against whitefly, and process for its preparation. Indian patent 228783:1-22

Houndété TA, Kétoh GK, Hema OS, Brévault T, Glitho IA, Martin T (2010) Insecticide resistance in field populations of Bemisia tabaci (Hemiptera: Aleyrodidae) in West Africa. Pest Manag Sci 66:1181-1185

Jin S, Zhang X, Daniell H (2012) Pinellia ternata agglutinin expression in chloroplasts confers broad spectrum resistance against aphid, whitefly, lepidopteran insects, bacterial and viral pathogens. Plant Biotechnol J 10: 313-327

Kontsedalov S, Abu-Moch F, Lebedev G, Czosnek H, Horowitz AR, Ghanim M (2012) Bemisia tabaci biotype dynamics and resistance to insecticides in Israel during the years 2008-2010. J Integr Agric 11:312-320

Luo C, Jones M, Devine G, Zhang F, Denholm I, Gorman K (2010) Insecticide resistance in Bemisia tabaci biotype Q (Hemiptera: Aleyrodidae) from China. Crop Prot 29:429-434

Macedo ML, Durigan RA, da Silva DS, Marangoni S, Md F, Parra JR (2010) Adenanthera pavonina trypsin inhibitor retard growth of Anagasta kuehniella (Lepidoptera: Pyralidae). Arch Insect Biochem Physiol 73:213-231

Macedo ML, Md F, Franco OL, Migliolo L, de Oliveira CF (2011) Practical and theoretical characterization of Inga laurina Kunitz inhibitor on the control Homalinotus coriaceus. Comp Biochem Physiol Part B 158:164-172

Navas-Castillo J, Fiallo-Olivé E, Sánchez-Campos S (2011) Emerging virus diseases transmitted by whiteflies. Annu Rev Phytopathol 49:219-248

Reitz SR (2007) Invasion of the whiteflies. Science 318:1733-1734
Saadati F, Bandani A (2011) Effects of serine protease inhibitors on growth and development and digestive serine proteinases of the Sunn pest, Eurygaster integriceps. J Insect Sci 11:1-12

Schaad NW, Jones JB, Chun W (2001) Laboratory guide for the identification of plant pathogenic bacteria. The American Phyto-pathological Society, St. Paul, MN, USA

Shen Y, Li J, Xiang J, Wang J, Yin K, Liu Q (2019) Isolation and identification of a novel protein elicitor from a Bacillus subtilis strain BU412. AMB Express 9:117

Shukla AK, Upadhyay SK, Mishra M, Saurabh S, Singh R, Singh H, Thakur N, Rai P, Pandey P, Hans AL, Srivastava S, Rajapure V, Yadav SK, Singh MK, Kumar J, Chandrashekar K, Verma PC, Singh AP, Nair KN, Bhadauria S, Wahajuddin M, Singh S, Sharma S, Omkar URS, Ranade SA, Tuli R, Singh PK (2016) Expression of an insecticidal fern protein in cotton protects against whitefly. Nat Biotechnol 34:1046-1051

Upadhyay SK, Chandrashekar K, Thakur N, Verma PC, Borgio JF, Singh PK, Tuli R (2011) RNA interference for the control of whiteflies (Bemisia tabaci) by oral route. J Biosci 36:153-161

Vassiliou V, Emmanouilidou M, Perrakis A, Morou E, Vontas J, Tsagkarakou A, Roditakis E (2011) Insecticide resistance in Bemisia tabaci from Cyprus. Insect Sci 18:30-39

Wang Z, Yao M, Wu Y (2009) Cross-resistance, inheritance and biochemical mechanisms of imidacloprid resistance in B biotype Bemisia tabaci. Pest Manag Sci 65:1189-1194

\section{Publisher's Note}

Springer Nature remains neutral with regard to jurisdictional claims in published maps and institutional affiliations.

\section{Submit your manuscript to a SpringerOpen ${ }^{\circ}$ journal and benefit from:}

- Convenient online submission

- Rigorous peer review

- Open access: articles freely available online

High visibility within the field

- Retaining the copyright to your article

Submit your next manuscript at $\boldsymbol{\nabla}$ springeropen.com 